\title{
Kleptoplast distribution, photosynthetic efficiency and sequestration mechanisms in intertidal benthic foraminifera
}

\author{
Bruno Jesus iD $^{1,2,9 凶}$, Thierry Jauffrais ${ }^{3,4,9}$, Erik C. L. Trampe iD $^{5}$, Johannes W. Goessling ${ }^{5}$, Charlotte Lekieffre ${ }^{6}$, Anders Meibom (iD ${ }^{7,8}$, \\ Michael Kühl (D) ${ }^{5}$ and Emmanuelle Geslin ${ }^{4}$
}

(c) The Author(s) 2021

\begin{abstract}
Foraminifera are ubiquitously distributed in marine habitats, playing a major role in marine sediment carbon sequestration and the nitrogen cycle. They exhibit a wide diversity of feeding and behavioural strategies (heterotrophy, autotrophy and mixotrophy), including species with the ability of sequestering intact functional chloroplasts from their microalgal food source (kleptoplastidy), resulting in a mixotrophic lifestyle. The mechanisms by which kleptoplasts are integrated and kept functional inside foraminiferal cytosol are poorly known. In our study, we investigated relationships between feeding strategies, kleptoplast spatial distribution and photosynthetic functionality in two shallow-water benthic foraminifera (Haynesina germanica and Elphidium williamsoni), both species feeding on benthic diatoms. We used a combination of observations of foraminiferal feeding behaviour, test morphology, cytological TEM-based observations and HPLC pigment analysis, with non-destructive, single-cell level imaging of kleptoplast spatial distribution and PSII quantum efficiency. The two species showed different feeding strategies, with $H$. germanica removing diatom content at the foraminifer's apertural region and $E$. williamsoni on the dorsal site. All $E$. williamsoni parameters showed that this species has higher autotrophic capacity albeit both feeding on benthic diatoms. This might represent two different stages in the evolutionary process of establishing a permanent symbiotic relationship, or may reflect different trophic strategies.
\end{abstract}

The ISME Journal (2022) 16:822-832; https://doi.org/10.1038/s41396-021-01128-0

\section{INTRODUCTION}

Foraminifera are unicellular eukaryotes that contribute significantly to the carbon and nitrogen biogeochemical cycles in marine habitats. They play a major role in carbon sequestrationaccounting for $32-80 \%$ of total carbonate buried in sediments $[1,2]$-and are key players in the marine nitrogen cycle via their denitrification and inorganic nitrogen assimilation activities [3-5]. Foraminifera employ a diversity of feeding and behavioural strategies encompassing heterotrophic, autotrophic and mixotrophic life styles [6-11]. This wide range of feeding strategies increases their capacity to occupy different ecological niches, allowing foraminifera to be found in most marine environments ranging from shallow-water to deep-sea basins and open oceans $[12,13]$.

Some benthic foraminifera are capable of sequestering chloroplasts from their microalgal food source, i.e. diatoms $[5,14-16]$ and retain them photosynthetically active in their cytosol $[15,17-19]$. This process of sequestering and exploiting foreign plastids is referred to as kleptoplastidy [20] and has been extensively studied in sacoglossan gastropods e.g. [20-22], ciliates e.g. [23], mixotrophic dinoflagellates e.g. [24], and other protists e.g. $[25,26]$. Kleptoplastidy can play an essential role in the host metabolism, converting heterotrophic organisms into mixotrophic organisms, e.g. the sacoglossan Elysia chlorotica [27] and the dinoflagellate Dinophysis acuta [24, 28]. Kleptoplastidic benthic foraminifera thrive in sedimentary habitats, ranging from lightexposed shallow-waters to the aphotic deep-sea under fully oxic to anoxic conditions [19, 29-34]. Foraminiferal kleptoplasts exhibit different functionality levels and different retention times in the host cell, ranging from a short lifetime (24-48 h) - with none or little photosynthetic functionality-to longer ( $>2$ weeks to 3 months) associations with the foraminiferal host showing high kleptoplast activity [15, 18, 19, 33].

It is known that foraminiferal kleptoplasts originate from diatoms, but their ultrastructure and abundance in hospite has only been studied in a limited number of foraminifera species $[16,19,31,33-41]$ and the uptake and regulation mechanisms of kleptoplasts remain largely unexplored [15, 18, 19, 34, 41, 42].

Known feeding mechanisms of kleptoplastidic foraminifera are limited to a few experimental observations of Haynesina germanica feeding on benthic diatoms [29, 43], where the foraminifer employs extracellular cracking of the diatom frustule before removing the cell content via the primary aperture and the latero-umbilical supplementary apertures [29]. The distribution

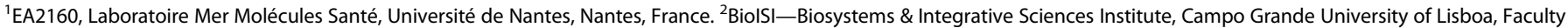

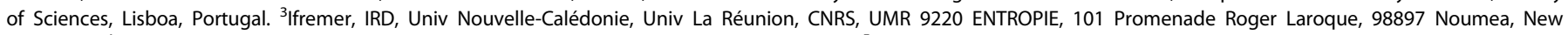

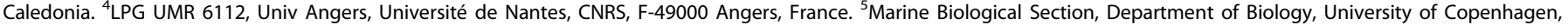

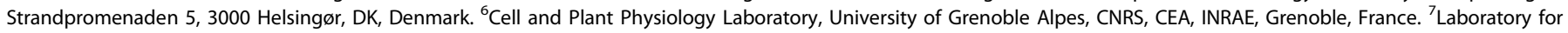

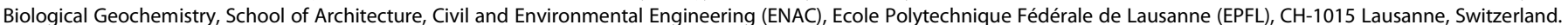

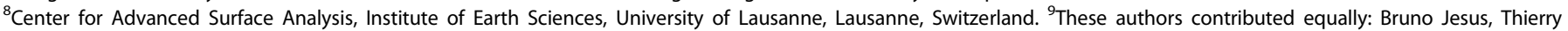
Jauffrais. ${ }^{凶}$ email: bruno.jesus@univ-nantes.fr 
and morphological changes of kleptoplasts after internalisation by the foraminiferal cells remain to be investigated in detail [39].

The cellular mechanisms by which kleptoplasts are kept functional and how they are incorporated in the foraminiferal heterotrophic cytosol are unknown. In most kleptoplastidic organisms, the nucleus of their algal prey is either discarded before assimilation or digested shortly after ingestion [24, 44, 45]. Although, kleptoplast genomes are kept intact after ingestion, it remains unknown how kleptoplasts are capable of sustained functionality since photosynthesis is strongly dependent on the synthesis of proteins encoded within algal nuclear genes [46]. Sustained kleptoplast functionality seems to be linked, at least partially, to host photo-regulatory capacities [22, 24, 47, 48]. Inside the host, kleptoplasts might avoid photo-damage either through inherent physiological photo-regulation mechanisms, such as the xanthophyll cycle and/or through host behavioural responses $[22,42,48]$. For example, in kleptoplastic sea slugs the behavioural responses include decreasing body surface and photophobic movements under high light exposure $[22,49]$ while symbioticbearing larger benthic foraminifera are capable of moving their algal symbionts away from light in response to light stress [50]. Presently, only four kleptoplastidic foraminifer species (all found on intertidal mudflats) have been described as photosynthetically active, i.e. Haynesina germanica, Elphidium crispum, Elphidium williamsoni and Planoglabratella opercularis [8, 14, 17-19, 34, 40], while the functionality of the xanthophyll cycle photo-regulation mechanism has only been studied in $H$. germanica [42].

In the present study, we investigate relationships between feeding strategies, kleptoplast spatial distribution and photosynthetic functionality in two shallow-water benthic foraminifera $(H$. germanica and $E$. williamsoni) exhibiting different kleptoplast retention-times and different levels of functionality $[14,18]$. This was achieved by coupling-for the first time-observations of foraminiferal feeding behaviour, test morphology, cytological TEM-based observations and HPLC pigment analysis, with nondestructive, single-cell level imaging of kleptoplast spatial distribution and kleptoplast photosystem II (PSII) quantum efficiency in live foraminifera. Our results show that the two foraminiferal species exhibit different mixotrophic capabilities, albeit colonising the same habitat and feeding on the same type of diatoms. This might be representative of two different stages in the evolutionary process of establishing a permanent symbiotic relationship between foramifera and diatomaceous chloroplasts, or may reflect different trophic strategies, with one species relying more on autotrophy and the other on heterotrophy.

\section{MATERIAL AND METHODS Specimen collection, identification and test morphology}

Haynesina germanica (elphidiid phylotype S16 [51], Fig. 1) specimens were collected from Bourgneuf Bay $\left(47^{\circ} 00^{\prime} 56.0^{\prime \prime} \mathrm{N} 2^{\circ} 01^{\prime} 30.7^{\prime \prime} \mathrm{W}\right.$, France) intertidal mudflat sediments $(\sim 0-0.5 \mathrm{~cm}$ depth) in November 2015 . Elphidium williamsoni (elphidiid phylotype S1 [51], Fig. 2) specimens were collected at the same period and with the same protocol in a small microtidal mudflat in Fiskebäckskil near Kristineberg Marine Research Station $\left(58^{\circ}\right.$

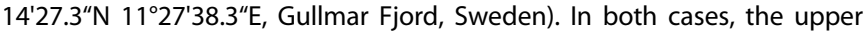
$(0.5 \mathrm{~cm}$ deep) sediment layer was sieved ( 300 and $150 \mu \mathrm{m}$ mesh size) using in situ seawater. The 150-300 $\mu \mathrm{m}$ fraction contained the majority of the targeted adult species and was collected in dark flasks and maintained in darkness at $16^{\circ} \mathrm{C}$ until further analysis (within 1-5 days). Species identification and characterisation of foraminiferal test morphology was carried out by separating foraminifera from the sediment with a brush and carefully cleaning live specimens. Cleaned specimens were then placed on micropalaeontological slides and imaged with an environmental scanning electron microscope (EVO LS10, ZEISS, Germany).

\section{HPLC pigment analysis}

Live foraminiferal specimens ( $n=300$ at each site) were separated and collected 1 day after sediment collection, using a stereomicroscope (Leica
MZ 12.5, Germany). Only foraminifera with visible cytoplasm inside their test were selected. Each specimen was carefully cleaned with a brush and rinsed in artificial seawater (ASW) to remove epiphyte contamination. Three replicates of 100 specimens (each in a $2 \mathrm{~mL}$ Eppendorf tube) from each location were snap-frozen in liquid $\mathrm{N}_{2}$ and kept at $-80^{\circ} \mathrm{C}$ until further analysis. Photopigments were extracted and quantified as described in [42]. Briefly, foraminifera were crushed in $300 \mu \mathrm{L}$ of a solution containing $95 \%\left(\mathrm{MeOH}: \mathrm{H}_{2} \mathrm{O} \mathrm{v} / \mathrm{v}\right)$ with $2 \%$ of ammonium acetate and an internal standard (trans- $\beta$-Apo-8'-carotenal) at a concentration of $1 \mathrm{mg} \mathrm{L}^{-1}$. The solution was sonicated $(1 \mathrm{~min})$, kept in the dark at $-20^{\circ} \mathrm{C}$ for $15 \mathrm{~min}$ and then filtered $(0.2 \mu \mathrm{m}$, Whatman) before injection of the filtrate on a highperformance liquid chromatography system (HPLC; Ultimate 3000 RS, Dionex). Pigments were identified from their absorption spectra (400-800 $\mathrm{nm}$ ) as recorded with the photodiode-array detector of the HPLC system. Pigment quantification, in ng per foraminifera cell (ng cell ${ }^{-1}$ ), was carried out at $440 \mathrm{~nm}$ by comparing sample absorption with absorption of pigment standards (DHI, Denmark). Results are shown for major diatom pigments: chlorophyll $a(\mathrm{Chl} a)$, chlorophyll $\mathrm{c1}+\mathrm{c2}(\mathrm{Chl} c)$, fucoxanthin (Fuco), diadinoxanthin (DD), diatoxanthin (DT), the sum of the xanthophyll cycle pigments $(\mathrm{XCP}=\mathrm{DD}+\mathrm{DT})$, phaeophytins and carotenoid degradation products (mainly composed of two types of Fuco-like degradation products, which we named Fuco-like 1 and Fuco-like 2).

\section{Single-cell spectral reflectance images}

Hyperspectral image stacks ( $400-800 \mathrm{~nm} ; 430$ spectral bands) of individual specimens were acquired using a hyperspectral image scan unit (100TVNIR, Themis Vision, Bay Saint Louis, MS, USA) mounted on a stereo microscope (SZ51, Olympus, Japan) [52]. Hyperspectral image stacks were processed using the software HyperVisual 3.0 (Themis Vision Systems, USA). Reflectance images were calculated using image stacks recorded over a 99\% Spectralon standard as a reference (Spectralon, Labsphere, North Sutton, NH, USA) and subtracting background noise from dark images.

The normalised difference vegetation index (NDVI) was used as a proxy for chlorophyll [53], where NDVI images were calculated as NDVI = (NIR Red)/(NIR + Red), where NIR corresponded to the $752 \mathrm{~nm}$ spectral band and Red corresponded to the $676 \mathrm{~nm}$ band in the calibrated image stacks. NDVI has been shown to correlate well with $\mathrm{Chl} a$ content in a variety of organisms including diatoms and sacoglossan sea slugs [54-57]. The pigment absorption signatures in the hyperspectral scans were also studied using second derivative analysis (see $[58,59]$ for a detailed description). Second derivative values of the complete image stacks were calculated for each pixel according to [60] and second derivative images for each wavelength were reconstructed using custom-made R scripts [61], thus allowing for the detection of small changes in absorption features that are not easily detected on reflectance images.

\section{Single-cell variable chlorophyll fluorescence imaging}

Variable $\mathrm{Chl} a$ fluorescence imaging of single foraminifera was done using a RGB Microscopy PAM variable chlorophyll fluorometer (Walz, Germany) mounted on an epifluorescence microscope (Axiostar FL plus, Zeiss) equipped with a $\times 20$-magnification objective. A detailed description of the imaging system and its calibration is available in [62]. All measurements were carried out using blue LED light $(\lambda=450 \mathrm{~nm})$ for weak measuring light pulses, strong saturating light pulses and defined levels of actinic light exposure.

Images of minimum fluorescence yield $\left(F_{0}\right)$ and of maximal fluorescence yield upon a strong saturation pulse $\left(\mathrm{F}_{\mathrm{m}}\right)$ were recorded and used to calculate images of the maximum PSIl quantum efficiency of dark acclimated specimens $(30 \mathrm{~min}), F_{v} / F_{m}=\left(F_{m}-F_{0}\right) / F_{m}$. Immediately after these measurements, images of minimum fluorescence yield $(F)$ and maximum fluorescence yield $\left(F_{m}^{\prime}\right)$ were recorded over a range of photon irradiances with nine incremental $10 \mathrm{~s}$ light steps $(3,17,30,50,78,112,152$, 201 and $254 \mu \mathrm{mol}$ photons $\left.\mathrm{m}^{-2} \mathrm{~s}^{-1}\right)$. These measurements were used to calculate the effective PSII quantum yield at each actinic photon irradiance level (photosynthetic active radiation, PAR, $\lambda=400-700 \mathrm{~nm}$ ) as $\phi_{\mathrm{PSII}}=$ $\left(\mathrm{F}_{m}^{\prime}-\mathrm{F}\right) / \mathrm{F}_{m}^{\prime}$

Furthermore, the relative PSIl electron transport rate at each photon irradiance level was calculated as: $r E T R=\phi_{P S I I} \times P A R$. Plotting rETR vs. photon irradiance generated so-called rapid light curves (RLC; [63]), which provide a snapshot of the photosynthetic capacity and photoacclimatory status of the investigated sample. RLC can be described similar to photosynthesis vs. irradiance curves exhibiting a light-limited initial slope (a) and approaching saturation (and sometimes inhibition) at higher 

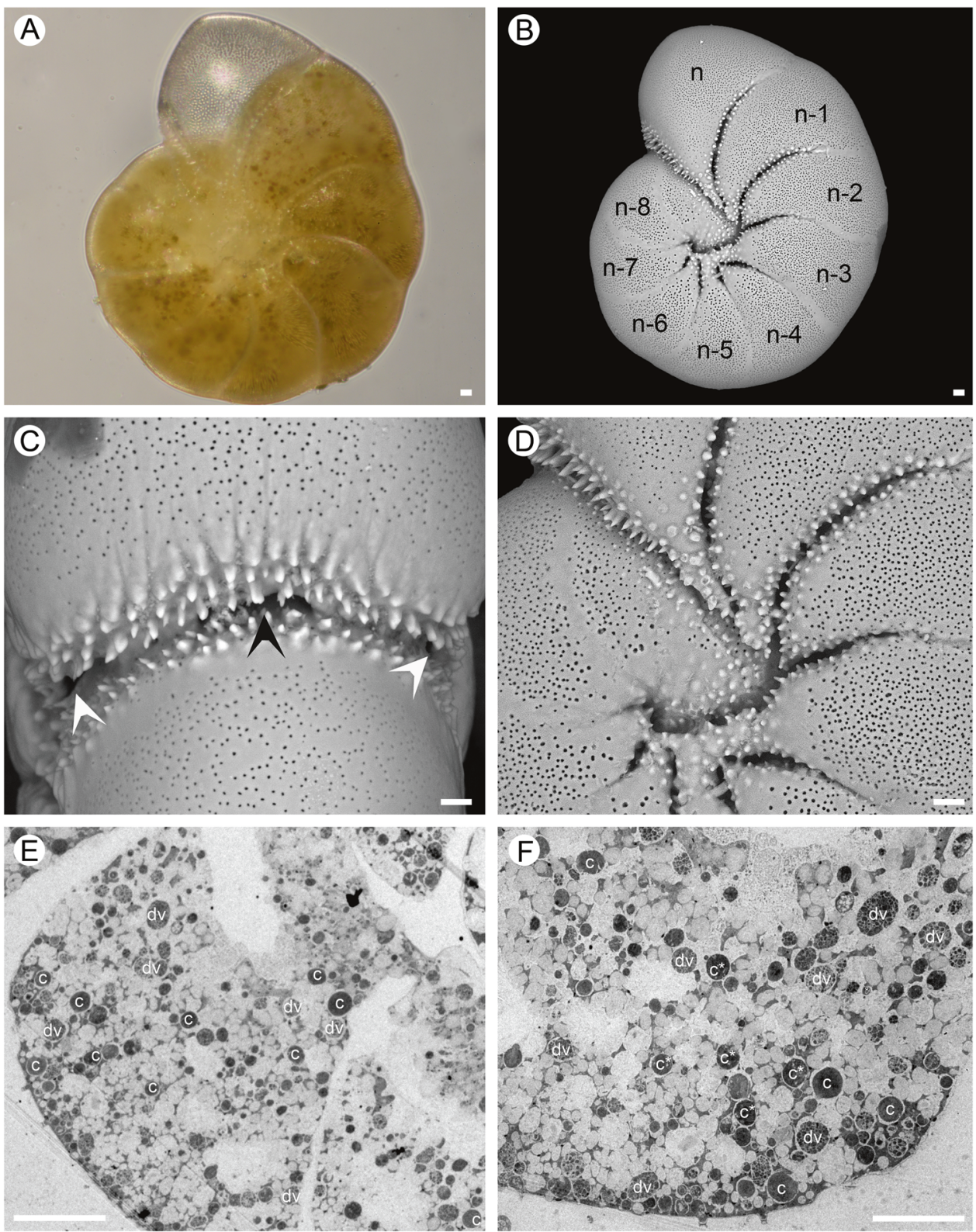

Fig. 1 Haynesina germanica (isolated from Bourgneuf Bay (France) intertidal sediments. A Light micrograph. B SEM micrograph. C-D SEM micrograph of apertural regions, main foramen (sometime divided/obscured by tuberculations) and a posterior-umbilical supplementary aperture, black and white arrowheads respectively. E-F TEM micrographs, overview of a chamber showing sequestered chloroplasts (c), degraded chloroplasts $\left(c^{*}\right)$ and digestive vacuoles (dv) Scale bars: $10 \mu \mathrm{m}$.

irradiances. RLC data were fitted by the function defined in [64] replacing production by rETR, i.e. $r E T R=r E T R_{s}\left[1-\exp \left(-a P A R / r E T R_{s}\right)\right] \exp (-\beta P A R /$ rETR $_{s}$ ), where rETR is the maximum potential rETR in the absence of photoinhibition, $\beta$ is the RLC slope beyond the onset of photoinhibition and $\alpha$ is the initial RLC slope at limiting irradiances [65]. rETR $\max$ was estimated using $\mathrm{rETR}_{\max }=\operatorname{rETR}_{\mathrm{s}}[\alpha /(\alpha+\beta)][\beta /(\alpha+\beta)]^{\beta / \alpha}$ as defined by [66]. The light saturation coefficient $\left(E_{k}\right)$ was calculated as $E_{k}=r E T R_{\max } / a$, corresponding to the photon irradiance value at the onset of photosynthesis saturation. Fitting was done using the non-linear Levenberg-Marquardt algorithm and the function nlsLM from the $\mathrm{R}$ package minpack. Im [67].

\section{Electron microscopy (TEM) imaging}

Specimens from each species were fixed in situ with a fixative solution $(4 \%$ glutaraldehyde and $2 \%$ paraformaldehyde in ASW), kept at room temperature $\left(18-20^{\circ} \mathrm{C}\right)$ for $24 \mathrm{~h}$ and then stored at $4{ }^{\circ} \mathrm{C}$ until further processing. Subsequently, samples were rinsed in ASW, decalcified in $0.1 \mathrm{M}$ EDTA (in distilled water, $\mathrm{pH} 7.4$ ) and post-fixed with $2 \%$ osmium tetroxide diluted in ASW for $1 \mathrm{~h}$. This was followed by dehydration of the samples in successive ethanol baths and embedding in LR White (Sigma-Aldrich) resin. Five specimens from each species were cut with an ultra-microtome (Reichert Ultracut S, Leica, Germany) and the ultra-thin $(70 \mathrm{~nm})$ sections were then stained with uranyl acetate (10 $\mathrm{min}, 2 \%$ aqueous uranyl acetate) prior to observation on transmission electron microscope (TEM; Philips 301 CM100, Netherlands) at an acceleration voltage of $80 \mathrm{kV}$. See [68] for a more detailed description of the experimental protocol. For both species, the study focused on chambers located in the external foraminiferal whorl (between $n-3$ and $n-8 ; n$ being the youngest chamber next to the aperture; Fig. $1 \mathrm{~B}$ and Fig. 2B). Mitochondrial integrity of all the specimens was checked by TEM to ensure the vitality of the studied specimens $[69,70]$.

\section{Feeding experiment}

The feeding behaviour of both foraminiferal species was recorded by placing healthy specimens (i.e. with cytoplasm visible inside the test; Fig. $1 \mathrm{~A}$ and Fig. 2A) in custom-built phytoplankton sedimentation chambers (diameter $=2 \mathrm{~cm}$, height $=3 \mathrm{~cm}$ ) filled with $A S W$, which were 

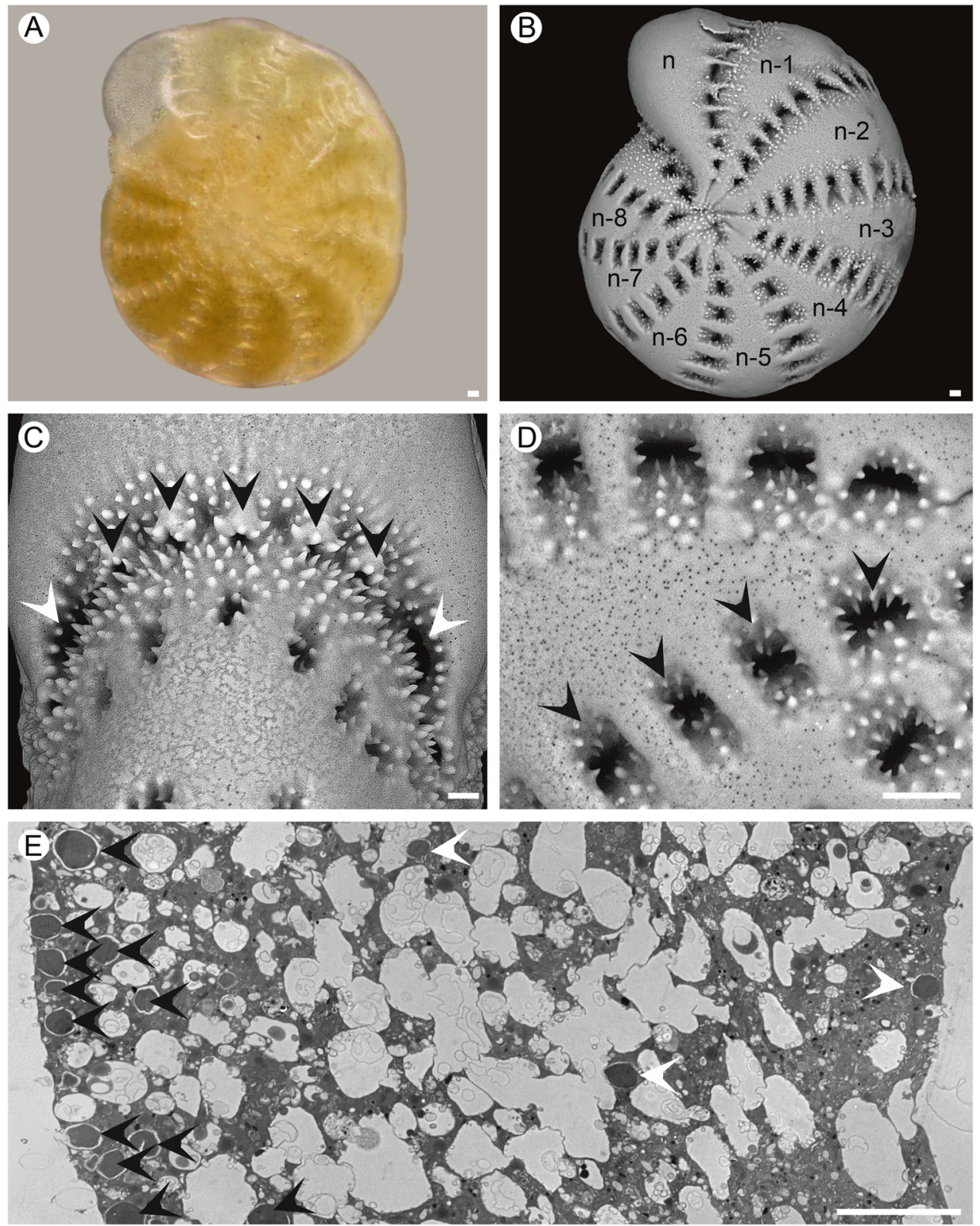

Fig. 2 Elphidium williamsoni isolated from Gullmar fjord (Sweden) intertidal sediments. A Light micrograph. B SEM micrograph. C-D SEM micrograph of the apertural region, numerous aperture and foramina equipped with a collar-like lip with tuberculations and posteriorumbilical supplementary apertures, black and white arrowheads, respectively. E TEM micrographs, overview of a chamber ( $n-3)$ showing sequestered chloroplasts at the periphery (black arrowheads) and internally (white arrowheads). Scale bars: $10 \mu \mathrm{m}$.

mounted on a reversed microscope (Axiovert 25, Zeiss, magnification $\times 50$ ) equipped with a SLR camera (Nikon D7000, Japan). Foraminifera were observed with an image acquisition interval of $15 \mathrm{~s}$, while being fed diatoms isolated from natural microalgal biofilms. Microphytobenthic (MPB) biofilms were collected at Bourgneuf Bay using the lens-tissue technique [71] and aliquots of diatoms were subsequently transferred with a glass pipette to the sedimentation chamber containing the foraminifer specimens. The feeding activity was recorded using individual photographs and animated into short video clips (5 images per second) using ImageJ software [72].

\section{Statistical procedures}

Statistical analysis consisted of one-way ANOVA or $t$-test (5\% significance level) depending on the number of conditions to test. Variance homogeneity and normality were tested with Bartlett and Shapiro tests, respectively. When homoscedasticity and normality were not observed, a non-parametric Wilcoxon test was applied. Data were expressed as mean values \pm standard error $(S E) . F_{v} / F_{m}$ values were arcsine transformed before statistical analysis was performed. All statistical analyses were carried out using the R software [73]. When applicable, ANOVA were followed by Tukey HSD posthoc tests to compare the different conditions.

\section{RESULTS}

\section{Feeding behaviour and relationship with test morphology}

Both foraminiferal species showed the presence of teeth and tubercules around the apertural region (Fig. 1C and Fig. 2C). However, while $H$. germanica had a smooth lateral surface with teeth and/or tubercules only present in the depressed part of the suture and of the umbilical region (Fig. 1B and Fig. 1D), E. williamsoni presented numerous teeth/tubercules around the fossettes and ponticuli at the lateral side of its test (Fig. 2B and Fig. 2D). Furthermore, E. williamsoni showed numerous teeth/ tubercules around the apertural and umbilical regions (Fig. 2C). These apertures were very different between the two species. 
Table 1. Pigment content per cell and pigment/chlorophyll a ratios in Haynesina germanica and Elphidium williamsoni (3 replicates of 100 specimens in each treatment).

\begin{tabular}{lllllll}
\hline Pigments (ng cell ${ }^{-1}$ ) & Chl $\boldsymbol{a}$ & Chl $\boldsymbol{c}$ & Fuco & DD & DT & Deg Pig \\
\hline H. germanica & $14.56 \pm 1.32$ & $1.60 \pm 0.10^{\mathrm{a}}$ & $6.16 \pm 0.37$ & $1.03 \pm 0.09^{\mathrm{a}}$ & $0.55 \pm 0.03$ & $5.25 \pm 1.02^{\mathrm{a}}$ \\
\hline E. williamsoni & $18.72 \pm 2.80$ & $1.19 \pm 0.18^{\mathrm{a}}$ & $5.32 \pm 0.69$ & $1.36 \pm 0.30^{\mathrm{a}}$ & $0.56 \pm 0.10$ & $1.92 \pm 0.34^{\mathrm{a}}$ \\
\hline Pigments $\left(\mathbf{g ~ g ~}^{-\mathbf{1}}\right.$ ) & Chl $\mathbf{c} / \mathbf{C h l} \boldsymbol{a}$ & Fuco/Chl $\boldsymbol{a}$ & DT/DD & DT/(DT + DD) & (DT + DD)/Chl $\boldsymbol{a}$ & Deg Pig/Chl $\boldsymbol{a}$ \\
\hline H. germanica & $0.11 \pm 0.01^{\mathrm{a}}$ & $0.43 \pm 0.05^{\mathrm{a}}$ & $0.54 \pm 0.03$ & $0.35 \pm 0.01$ & $0.11 \pm 0.01$ & $0.37 \pm 0.037^{\mathrm{a}}$ \\
\hline E. williamsoni & $0.06 \pm 0.01^{\mathrm{a}}$ & $0.28 \pm 0.01^{\mathrm{a}}$ & $0.42 \pm 0.09$ & $0.29 \pm 0.04$ & $0.10 \pm 0.005$ & $0.10 \pm 0.003^{\mathrm{a}}$ \\
\hline
\end{tabular}

${ }^{\mathrm{a} S}$ Significant difference at $p<0.05$ (Wilcoxon test).

Haynesina germanica showed an apertural arch often obscured by "tuberculation", thus with 3-4 foramina: one main foramen (sometimes divided/obscured by tuberculations) and posteriorumbilical supplementary apertures, one each side (Fig. 1C). Elphidium williamsoni apertures and foramina were numerous and each of them equipped with a collar-like lip with tuberculations; this species also showed posterior-umbilical supplementary apertures on each side of the apertural region (Fig. 2C).

While both $H$. germanica (Video 1) and E. williamsoni (Video 2) captured diatoms using their network of pseudopodia followed by extracellular cracking of the silicate diatom cell wall (frustule) and extraction of the algal cytoplasm, a clear difference in feeding behaviour was found between the two species. In $\mathrm{H}$. germanica the extracellular cracking of the diatom frustule and removal of diatom cytoplasm occurred at the foraminifer's apertural region (Video 1 and Fig. 1C, black and white arrow heads); whereas in $E$. williamsoni both events occurred on the dorsal sides of the test, where the toothed fossettes are located (Video 2 and Fig. 2B, D, black and white arrow head).

\section{Cytological TEM analysis}

The analysis of $H$. and E. williamsoni TEM images showed two different intracellular kleptoplast distribution patterns. In all the observed specimens of the species $H$. germanica, kleptoplasts were evenly distributed inside the foraminifer's chambers (Fig. 1E, F). In E. williamsoni specimens, kleptoplasts were mainly concentrated at the periphery of the chambers below the organic lining and the shell (Fig. 2E). In both species most of the observed kleptoplasts were intact and exhibited fine structural details, although some kleptoplasts showed signs of degradation (Fig. 1E, F; Fig. 2E). The cytoplasm of $H$. germanica specimen exhibited more degradation vacuoles than in E. williamsoni.

\section{Foraminiferal pigment content}

Haynesina germanica and E. williamsoni showed no qualitative differences in their photo-pigmentation, with all detected pigments being characteristic of diatoms. The major photopigments in both foraminiferal species were chlorophyll $a$ (Chl a), chlorophyll $c(\mathrm{Chl} c)$, fucoxanthin (Fuco), diadinoxanthin (DD) and diatoxanthin (DT) (Table 1, Fig. SI 1). However, $\mathrm{Chl} c$ and Fuco ratios relative to $\mathrm{Chl} a$ were higher in $H$. germanica than in $E$. williamsoni ( $p<0.05, n=3$; Table 1$)$. Also, the ratio of degradation pigments to $\mathrm{Chl} a$ and the amount of pigment degradation per cell were more than twofold higher in $H$. germanica $(p<0.05)$ (Table 1).

\section{Hyperspectral imaging}

NDVI showed significant differences ( $p<0.01$; $t$-test) between the two species, with $E$. williamsoni showing average values twofold higher than $H$. germanica $(0.38 \pm 0.02$ and $0.20 \pm 0.03$, respectively). Analyses of the NDVI distribution throughout the different foraminiferal test chambers (Fig. 3) showed that both species had heterogeneous NDVI distribution throughout the host cell in $H$. germanica $\left(F_{8,45}=10.53, p<0.001\right)$ and $E$. williamsoni $\left(F_{10,50}=\right.$
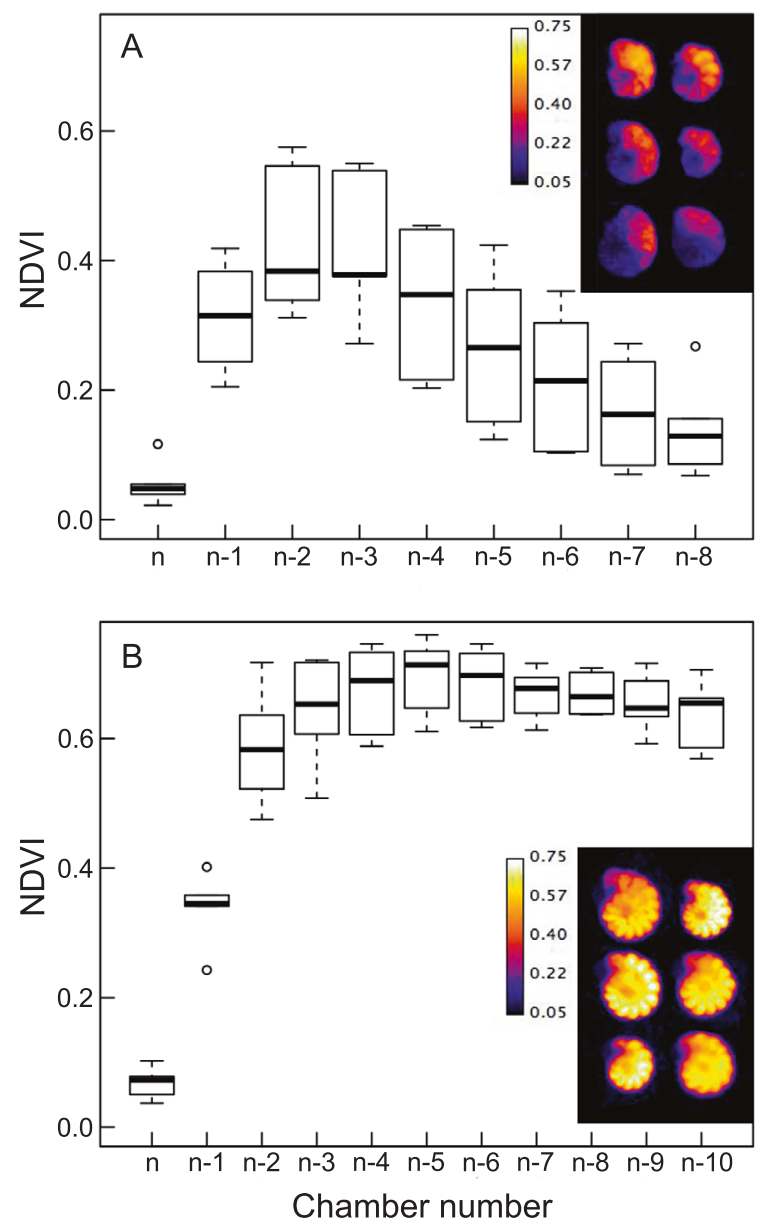

Fig. 3 Normalised difference vegetation index (NDVI) per foraminiferal chamber. A Haynesina germanica; B Elphidium williamsoni; $\mathrm{n}$ being the last chamber formed.

$70.56, p<0.001)$. However, the type of spatial distribution differed between the two species. In $H$. germanica, NDVI values were highest in the most recently formed chambers $n-2$ and $n-3$ and then progressively decreased towards the oldest chamber (Fig. 3A), while NDVI values in E. williamsoni showed a more homogenous distribution overall chambers with no obvious NDVI decrease from chamber n-2 to n-10 (Fig. 3B). In E. williamsoni, Tukey HSD posthoc tests showed that NDVI in chambers $n$ and $n-1$ differed significantly from all subsequent chambers (Fig. 3B). In contrast, $H$. germanica showed significant NDVI differences between chamber $n$ and all chambers up to chamber $n-4$, while chambers $n-6$ to $n-8$ showed no differences from the youngest and last chamber built (n) (Fig. 3A). 


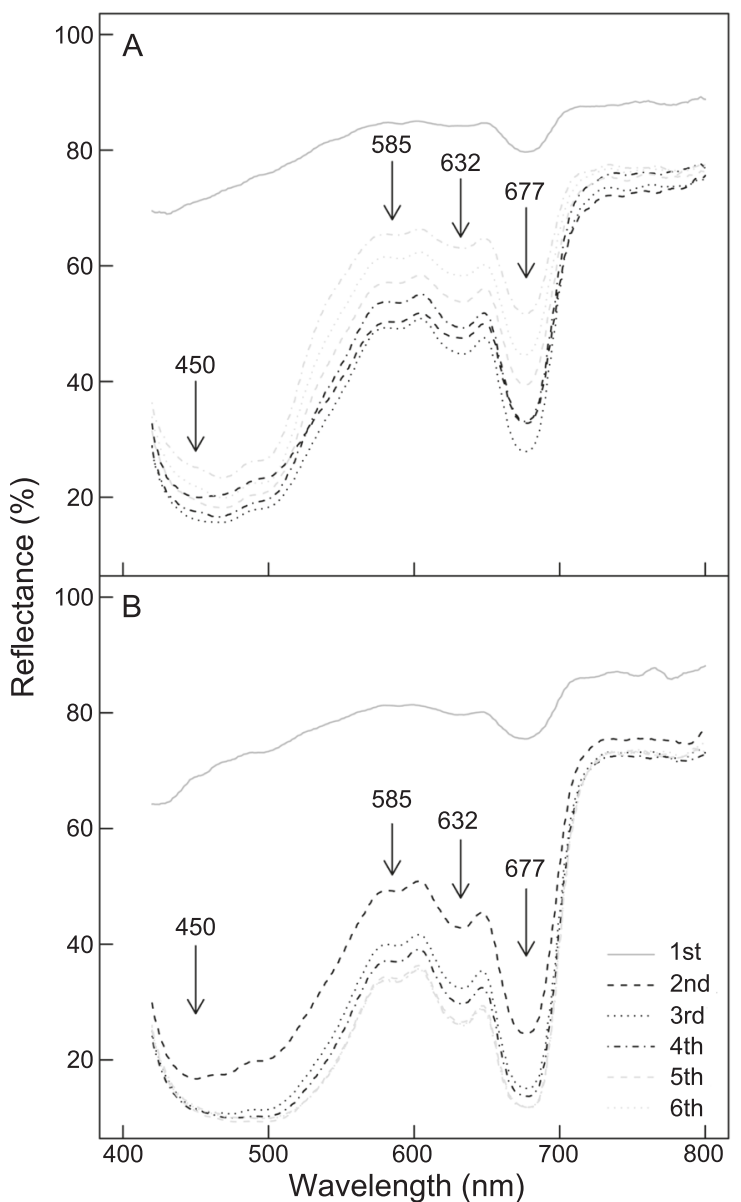

Fig. 4 Spectral reflectance signatures of the two foraminiferal species. Reflectance averages $(\%, n=6)$ per foraminiferal chamber for Haynesina germanica $(\mathbf{A})$ and Elphidium williamsoni $(\mathbf{B}), \mathrm{n}$ being the last chamber formed.

Spectral signatures in the hyperspectral images showed typical diatom absorption features, with strong absorption features at $\lambda$ $=450,585$ and $675 \mathrm{~nm}(\mathrm{Chl} \mathrm{a})$ and $635 \mathrm{~nm}(\mathrm{Chl} \mathrm{c})$ (Fig. 4). Spectra measured at the centre of each chamber showed different spatial patterns for each species. Haynesina germanica showed typical diatom reflectance spectra without any obvious mark of pigment degradation in chambers $n-1, n-2$ and $n-3$, whereafter increasing pigment degradation was apparent in the spectral signature-as seen by the overall flattening of the shape and decrease of the absorption features (Fig. 4A); with the exception of the youngest chamber (n), in E. williamsoni, spectral signatures showed no obvious differences from the n-1 chamber towards the oldest chambers (n-10; Fig. 4B). Second derivative analysis showed that the signatures of pigment degradation products observed in $H$. germanica reflectance spectra were paralleled with an overall decrease in second derivative peaks and an increase of a peak at $507 \mathrm{~nm}\left(\delta \delta_{507}\right)$, while these changes were much smaller in $E$. williamsoni (Fig. 5). Mapping of $\delta \delta_{507}$ showed that the pigment responsible for this absorption feature was strongly concentrated in the older chambers in $\mathrm{H}$. germanica and was also present in higher concentrations in the youngest $E$. williamsoni chamber (Fig. SI 2). Quantification of $\delta \delta_{507}$ peaks showed that values in $H$. germanica were 2.5 times higher than in E. williamsoni (Fig. SI 2).

\section{Photosynthetic efficiency}

Overall, $F_{v} / F_{m}$ values indicative of the maximum PSII quantum yield were significantly different between the two species $(t=$ $7.95, \mathrm{df}=3.77, p<0.005)$, where $\mathrm{F}_{\mathrm{v}} / \mathrm{F}_{\mathrm{m}}$ in $E$. williamsoni was almost

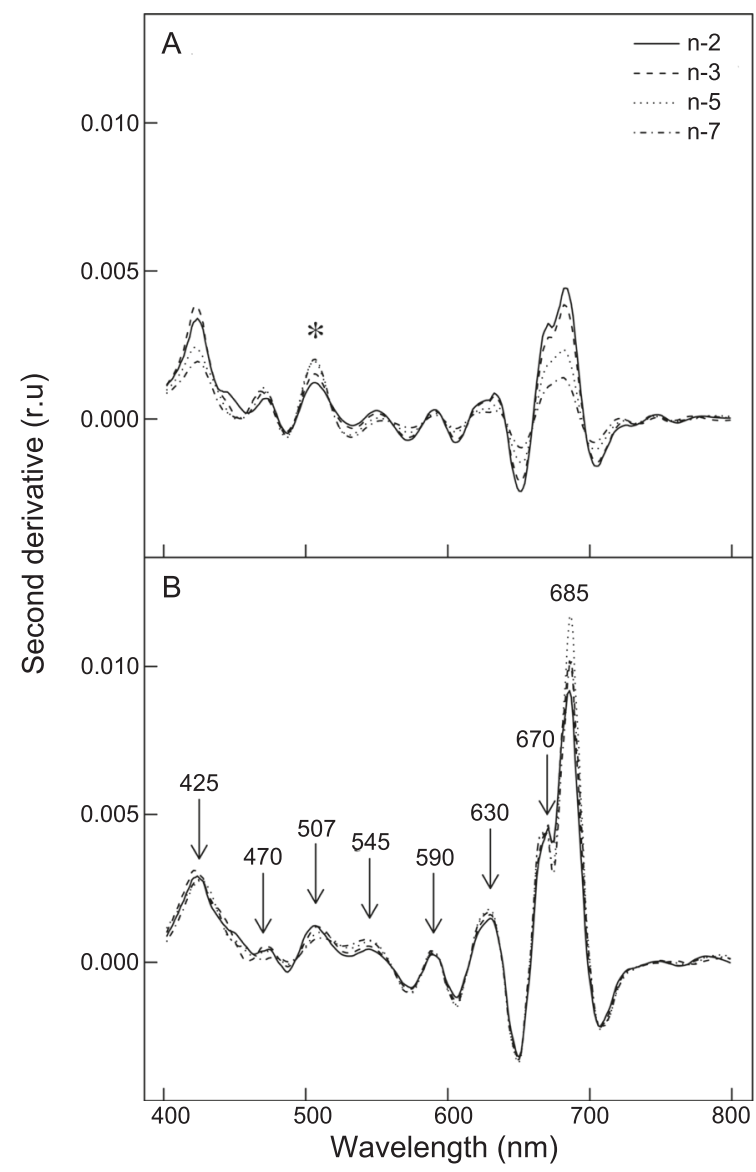

Fig. 5 Second derivative spectra of the two foraminiferal species. Second derivative averages $(\%, n=6)$ per foraminiferal chamber for Haynesina germanica (A) and Elphidium williamsoni (B), $\mathrm{n}$ being the last chamber formed.

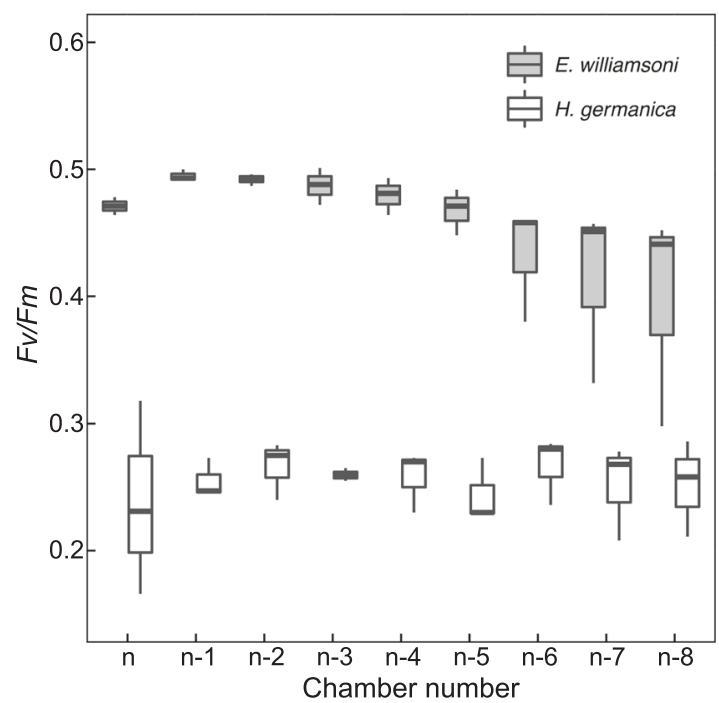

Fig. 6 PSII maximum quantum efficiency $(F v / F m)$ per foraminiferal chamber. A Haynesina germanica; B Elphidium williamsoni; $\mathrm{n}$ being the last chamber formed.

two-times higher than in $H$. germanica $(0.46 \pm 0.04$ and $0.25 \pm 0.03$, respectively). In both species, $F_{v} / F_{m}$ did not differ between chambers (Fig. 6).

With the exception of rETR $_{\max }$, all RLC parameters showed significant differences (ANOVA, $p<0.05$ ) between the two 

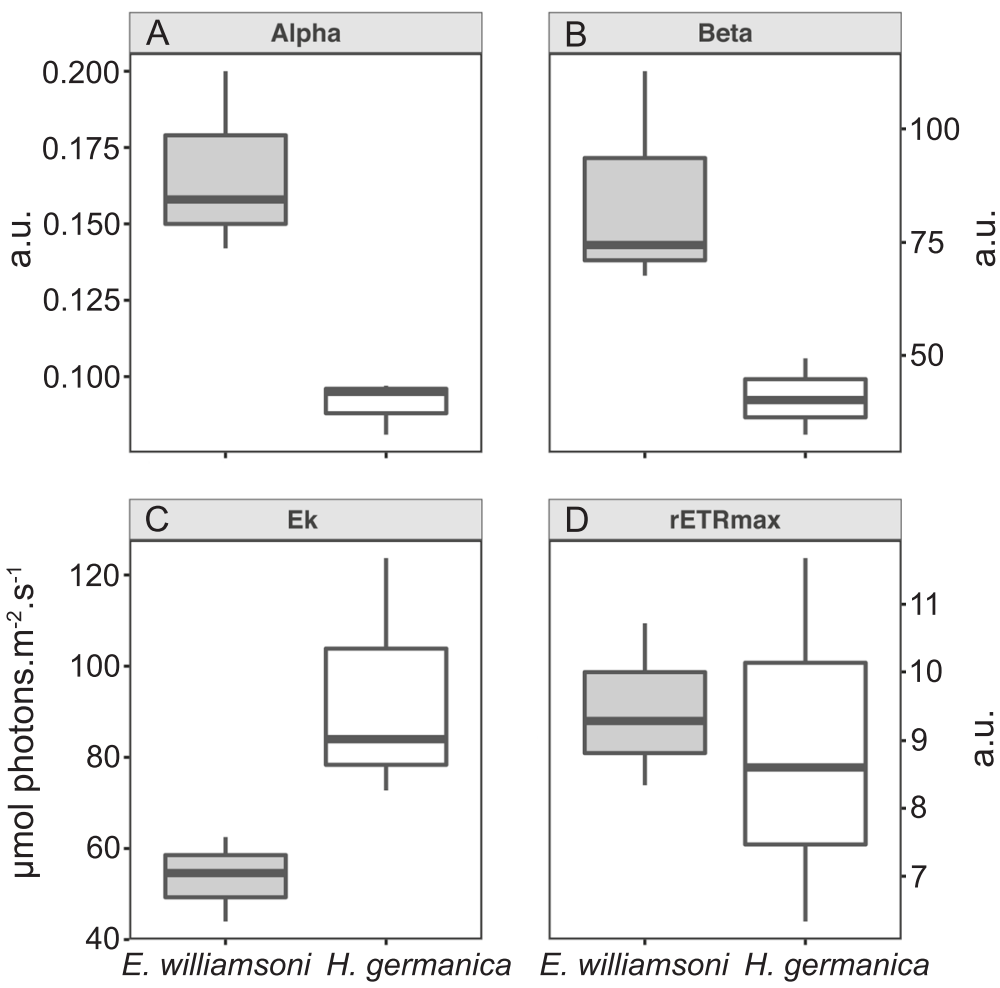

\section{Species}

Fig. 7 Rapid light curve (RLC) parameters for Haynesina germanica and Elphidium williamsoni $(\boldsymbol{n}=6)$. A Alpha, initial slope of the RLC at limiting irradiance. B Beta, photo-inhibition parameter. C Ek, light saturation coefficient. D rETRmax, maximum relative electron transport rate. a.u., arbitraty units.

foraminiferal species (Fig. 7); where E. williamsoni showed obvious features of being acclimated to lower light levels, i.e. higher $a$, lower $E_{k}$ and higher $\beta$ than $H$. germanica (Fig. 7).

The minimum fluorescence yield $\left(\mathrm{F}_{0}\right)$ showed a similar pattern to NDVI for both species (Fig. SI 3). In $H$. germanica, the highest $F_{0}$ values were measured in the younger chambers $n-2$ and $n-3$, followed by a decrease towards the oldest chamber (n-8). In $E$. williamsoni, $\mathrm{F}_{0}$ showed a more homogenous distribution throughout all the chambers with no obvious decrease after the two youngest chambers ( $n$ and $n-1$; Fig. SI 3 ).

RLC parameters did not show any obvious differences between chambers with the exception of $E$. williamsoni $\mathrm{rETR}_{\max }$ values $\left(F_{8,18}=\right.$ 2.903, $p=0.0288$ ) that decreased from $n-1$ to $n-8$ (Fig. SI 4). No significant differences in $a, E_{k}$ and $\beta$ were found between chambers in both species.

\section{DISCUSSION}

Mixotrophic growth involving the acquisition and functionalization of prey chloroplasts in the host is a widespread trait among protists [24-26, 74], which can have a significant impact in the microbial food web [26]. Although the role of foraminiferal mixotrophy has been mostly investigated in planktonic communities (e.g. [25] and references within), host-kleptoplast interactions $\left(\mathrm{O}_{2}\right.$ production, carbon- and nitrogen uptake) are also thought to play an important role in the physiology and biogeochemical features of some kleptoplastidic benthic foraminifera species [5, 14, 15, 17-19]. However, our knowledge of the feeding, photobiology and other autecological traits of these protists remain scarce. In the present study, the two foraminiferal species $H$. germanica and $E$. williamsoni showed differences in feeding mechanisms and in kleptoplast functionality (spatial distribution, PSII quantum efficiency, pigment profiles) suggesting that both species are capable of sustaining active chloroplasts (kleptoplasts) but with different functionality levels.

\section{Feeding mechanisms and kleptoplast assimilation}

The morphology of Haynesina germanica and Elphidium williamsoni has been described in detail [29,75-77] and some authors have speculated that both species would be able to use their test ornamentation to break diatom frustules and remove cytoplasm from the diatom cells using their pseudopods [29, 31, 78]. It was shown that $H$. germanica is capable of breaking Pleurosigma angulatum frustules using the foraminiferal test ornamentation found at the main aperture on the newest chamber [43]. Our results support a strong link between the test morphological features of kleptoplastidic foraminifera and their feeding behaviour (Video 1 and Video 2). We observed that foraminiferal pseudopods can touch and grip diatom cells, but it was only when the diatom frustules got in contact with the foraminiferal test that they were emptied of their cytoplasm content. This suggests that the physical contact with the foraminiferal test-rather than the handling by the pseudopods-breaks the diatom frustule. Our video observations, together with the SEM analysis of the different morphological features, suggests that $H$. germanica fractured the large benthic diatom frustules around the foraminiferal apertural and umbilical ornamentation, followed by the assimilation of the diatom cytoplasm content, supporting the observations of Austin et al. [43]. Similarly, E. williamsoni actively used its pseudopods to capture diatoms but seemed to use a different strategy, where the large pennate diatom frustules were fractured using the fossette "teeth" on the dorsal side of the foraminiferal test, with the diatom cytoplasm content being transported through the fossette to the umbilical canal and subsequently assimilated as previously theorised [29, 31, 78]. Although the video observations clearly showed large diatoms being targeted and incorporated inside the 
foraminifera, the pixel resolution of the videos was not sufficient to exclude the possibility that kleptoplasts from smaller diatoms were also being incorporated.

\section{Pigment and kleptoplast distribution in foraminifera}

The main photopigments detected in both species of foraminifera were of diatom origin, i.e. two chlorophylls ( $\mathrm{Chl} a$ and $\mathrm{Chl} \mathrm{c}$ ) and three carotenoids (Fuco and its by-products fuco-like- 1 and fucolike-2, as well as DD and DT). These pigments profiles were similar to pigments detected in microphytobenthos and benthic diatoms from mudflat environments [79-82] and confirmed previous studies concerning foraminiferal kleptoplast origin [18, 42, 83]. Although global pigment content was similar between the two investigated foraminiferal species, their pigment profiles were significantly different, probably reflecting differences in pigment ratios between the diatoms from the two sampling sites. Furthermore, $H$. germanica showed higher concentrations of degraded pigments, suggesting that this species has a lower ability to maintain healthy chloroplasts in comparison to $E$. williamsoni.

A difference between the two foraminifera in their ability to sustain kleptoplast functionality was further supported by hyperspectral imaging, which showed distinct differences in kleptoplast cellular distribution between the two species (Fig. 3). Whereas $\mathrm{H}$. germanica showed a strong decrease in NDVI (a proxy for chlorophyll content) from the younger chambers to the oldest one-suggesting that pigments were being degraded in the older chambers-E. williamsoni showed no obvious decrease in pigmentation across its chambers (Fig. 3). The decrease in NDVI in older $H$. germanica chambers was matched by an overall decrease in pigment absorption features, generating spectral reflectance signatures that were smoother than in the younger chambers (Fig. 4); this smoothing is further evidence that the pigments were being degraded and losing their absorption features. Second derivative analysis of spectral reflectance changes showed that the changes in $\mathrm{H}$. germanica spectra were accompanied by a concomitant increase of a second derivative peak at $507 \mathrm{~nm}$. We hypothesise that the increase in this second derivative peak is indicative of increased amounts of degraded pigments (Fig. 5). Kleptoplasts exhibited a gradual degradation from the younger towards the older chambers in $H$. germanica, whereas, E. williamsoni showed no evidence of pigment degradation along chambers. We therefore conclude that kleptoplastidic acquisition and retention mechanisms differ between the two foraminiferal species.

Strikingly, while E. williamsoni exhibited higher NDVI than $H$. germanica (Fig. 3), the Chl a content was similar between the two species (Table 1). This apparent inconsistency is likely the result of the different kleptoplast distributions inside the two foraminifera. Ultrastructural TEM analysis showed that $H$. germanica kleptoplasts were evenly distributed in their chambers (Fig. 1E and Fig. 1F), while $E$. williamsoni kleptoplasts were often concentrated at the edge of the test surface (Fig. 2E). Spectral reflectance measurements are mainly limited to the light reflected by the surface of observed samples. Thus, stronger kleptoplast concentration at the test surface of $E$. williamsoni is likely to increase the signal measured by the hyperspectral camera in comparison to $H$. germanica where deeper kleptoplasts will not be detected, resulting in a biased estimation of total chlorophyll inside this species, i.e. lower NDVI values.

\section{Photosynthetic activity within the foraminiferal cell}

The two foraminiferal species seemed to be acclimated to different light regimes, where $E$. williamsoni was apparently acclimated to lower light levels, as indicated by the RLCs, which exhibited higher $a$, lower $E_{k}$ and higher $\beta$ than $H$. germanica (Fig. 7). Photosynthesis in organisms acclimated to lower light levels typically exhibit saturation at lower light levels (i.e. lower $E_{k}$ ) and exhibit more photo-inhibition at higher light levels (i.e. higher $\beta$ ) [84]. Elphidium williamsoni also showed significantly higher DD content per cell (Table 1). This pigment, when exposed to light, is converted to the photo-protective pigment DT that dissipates excess light energy via non-photochemical quenching (NPQ; [85]). Thus, E. williamsoni would be capable of generating NPQ at lower light levels than $H$. germanica [86]. This is coherent with the different latitudes and solar exposure regimes of the sampling locations, i.e. Bourgneuf Bay (France) for H. germanica and Gullmar Fjord (Sweden) for E. williamsoni, confirming the observation by [42] that $H$. germanica kleptoplasts retain the photo-acclimation status of the diatoms from where they were extracted.

It remains unknown whether the kleptoplasts, once inside the foraminifera, are still capable of photo-acclimation by adjusting their pigment contents to cope with changes in ambient light. This does not seem to be the case in the $H$. germanica, where kleptoplast degradation is too fast for pigment synthesis [42], but it might be a possibility in $E$. williamsoni, which seems to maintain functional kleptoplasts for much longer [14]. Photo-acclimation has been has been observed in other kleptoplastidic organisms, e.g. in the dinoflagellate Dinophysis acuta [24].

On average, $H$. germanica $F_{v} / F_{m}$ values were significantly lower than in $E$. williamsoni ( 0.25 and 0.46 , respectively), further supporting our interpretation that $H$. germanica has a lower capacity to sequester and keep functional kleptoplasts, combined with lower kleptoplast retention time, as compared to E. williamsoni. In previous studies, $H$. germanica and $E$. williamsoni were both found to produce $\mathrm{O}_{2}$, indicative of actively photosynthesising kleptoplasts [14, 17-19]. However, E. williamsoni showed a tenfold higher $\mathrm{O}_{2}$ production rate [14] and higher inorganic carbon uptake rates (five times more) as compared to $H$. germanica [19]. Our variable $\mathrm{Chl}$ a fluorescence data confirm these previous observations by showing lower PSIl quantum efficiencies in $\mathrm{H}$. germanica compared to $E$. williamsoni. Thus, we can hypothesise that autotrophy via kleptoplastidy will have different importance for the overall metabolism in the two foraminifera. Haynesina germanica is probably more dependent on heterotrophy, requiring constant incorporation of fresh diatomaceous chloroplasts in order to sustain constant autotrophic rates, while the longer retention time of functional kleptoplasts in E. williamsoni renders this species less dependent on acquisition of fresh diatomaceous chloroplasts.

This hypothesis of uneven dependency on autotrophy in the two foraminiferal species is supported by recent findings that the trophic position of kleptoplastidic or symbiotic foraminiferal species relies on their microhabitat variability and on the resource used by the host and symbionts [9]. Microphytobenthic biofilms are concentrated in the top $500 \mu \mathrm{m}$ increasing the chances of biotic competition and reduction of available ecological niches. Kleptoplastidic foraminifera with higher $F_{v} / F_{m}$ might therefore rely more on their kleptoplasts for $\mathrm{C}$ and $\mathrm{N}$ fixation, which might lower their trophic position by improving their mixotrophic ability and decreasing their direct competition with more heterotrophic species.

The observed $F_{v} / F_{m}$ differences might also be partially explained by the different kleptoplast distribution within foraminifera chambers as discussed above. It has been suggested $[39,41]$ that a peripheral distribution of kleptoplasts in the tests of E. williamsoni (Fig. 2E) might be an adaptation for increasing their light exposure and improving gas exchanges with the exterior environment. In comparison, $H$. germanica kleptoplasts are distributed much more internally (Fig. 1E and Fig. 1F) and this might be a mechanism to protect the kleptoplasts from excessive light due to the lack of other physiological photo-protection mechanisms or just a passive result of foraminiferal cytosol movement.

Overall, the combined analysis of pigment and imaging data strongly supports the hypothesis that the observed $F_{v} / F_{m}$ 
differences between the two foraminifera were the result of increased kleptoplast maintenance mechanisms in E. williamsoni, resulting in kleptoplasts that were healthier and more functional in comparison to $H$. germanica. Thus, kleptoplast functionality in benthic foraminifera seems to be species-specific, similarly to what has been observed in other kleptoplastidic organisms, such as sacoglossan molluscs $[48,87,88]$.

Our results highlight different trophic strategies among kleptoplastidic foraminifera species living in similar habitats and feeding on the same resource, i.e. benthic diatoms. We speculate that such mixotrophic lifestyle is an adaptive mechanism that explains the foraminiferal capacity to colonise the complex microhabitats of intertidal marine sediments. We propose that different levels of kleptoplast functionality increase the range of sediment niches that the foraminifera are capable of occupying. Such functionality ranges from (i) very low kleptoplast functionality, e.g. in Ammonia T6 [89] with a very low capacity to retain functional kleptoplasts (<24 h [18]), over (ii) 'some' functionality, e.g. in $H$. germanica that can use its kleptoplasts to fix inorganic carbon but with a low ability to repair or maintain functional kleptoplasts under light exposure (7 days [8, 18], present study), to (iii) strong functionality, e.g. in E. williamsoni that is capable of photosynthesising and keeping healthy kleptoplasts for at least 15 days under light exposure [5], present study.

In conclusion, kleptoplast sequestration strategies and photosynthetic functionality of kleptoplasts seem to be species-specific in benthic foraminifera from shallow-waters and intertidal habitats. These morphological, ultrastructural and photo-physiological differences between the two investigated foraminifera species suggest that kleptoplast acquisition, use and maintenance mechanisms are major adaptive processes enabling high foraminiferal biomass and different species feeding on the same resource. This is strongly supported by a better photo-physiological state (e.g. $\left.>F_{v} / F_{m}\right)$ and longer retention times of functional kleptoplasts in $E$. willamsoni than in $H$. germanica, which are prerequisite to improve their mixotrophic ability. Also, our observations of feeding behaviour showed that the two species assimilate kleptoplasts via different mechanisms, resulting in substantially different distribution of kleptoplasts inside the foraminifera cell. This might be an adaptive trait for increasing kleptoplast light exposure and improving gas exchange with their environment. Thus, kleptoplastidy in these species seems to plays a central role in their metabolic strategies, supplying them with different levels of mixotrophic capacities, but it remains to be studied how such differences enable niche differentiation in MPB communities.

\section{REFERENCES}

1. Schiebel R. Planktic foraminiferal sedimentation and the marine calcite budget. Glob Biogeochem Cycl. 2002;16:1-21.

2. Lampitt RS, Salter I, John D. Radiolaria: major exporters of organic carbon to the deep ocean. Glob Biogeochem Cycl. 2009;23:GB1010.

3. Risgaard-Petersen N, Langezaal AM, Ingvardsen S, Schmid MC, Jetten MSM, Op den Camp HJM, et al. Evidence for complete denitrification in a benthic foraminifer. Nature. 2006;443:93-6.

4. Piña-Ochoa E, Hogslund S, Geslin E, Cedhagen T, Revsbech NP, Nielsen LP, et al. Widespread occurrence of nitrate storage and denitrification among foraminifera and gromiida. Proc Natl Acad Sci USA. 2010;107:1148-53.

5. Jauffrais T, LeKieffre C, Schweizer M, Geslin E, Metzger E, Bernhard JM, et al. Kleptoplastidic benthic foraminifera from aphotic habitats: insights into assimilation of inorganic C, N and S studied with sub-cellular resolution. Environ Microbiol. 2019;21:125-41.

6. Delaca TE, Karl DM, Lipps JH. Direct use of dissolved organic-carbon by agglutinated benthic foraminifera. Nature. 1981;289:287-9.

7. Moodley L, Boschker HTS, Middelburg JJ, Pel R, Herman PMJ, de Deckere E, et al. Ecological significance of benthic foraminifera: C-13 labelling experiments. Mar Ecol Prog Ser. 2000;202:289-95.

8. LeKieffre C, Jauffrais T, Geslin E, Jesus B, Bernhard JM, Giovani ME, et al. Inorganic carbon and nitrogen assimilation in cellular compartments of a benthic kleptoplastic foraminifer. Sci Rep. 2018;8:1-12.
9. Tsuchiya M, Chikaraishi Y, Nomaki H, Sasaki Y, Tame A, Uematsu K, et al. Compound-specific isotope analysis of benthic foraminifer amino acids suggests microhabitat variability in rocky-shore environments. Ecol Evol. 2018;8:8380-95.

10. Glock N, Roy AS, Romero D, Wein T, Weissenbach J, Revsbech NP, et al. Metabolic preference of nitrate over oxygen as an electron acceptor in foraminifera from the Peruvian oxygen minimum zone. Proc Natl Acad Sci USA. 2019;116:2860-5.

11. Woehle C, Roy AS, Glock N, Wein T, Weissenbach J, Rosenstiel P, et al. A novel eukaryotic denitrification pathway in foraminifera. Curr Biol. 2018;28:1-8.

12. Gooday A. Meiofaunal foraminiferans from the bathyal porcupine seabight (northeast Atlantic): size structure, standing stock, taxonomic composition, species diversity and vertical distribution in the sediment. Deep-Sea Res Part A Oceanogr Res Pap. 1986;33:1345-73.

13. Pascal P-Y, Dupuy C, Richard P, Mallet C, Telet EAC, Niquilb N. Seasonal variation in consumption of benthic bacteria by meio- and macrofauna in an intertidal mudflat. Limnol Oceanogr. 2009;54:1048-59.

14. Jauffrais T, LeKieffre C, Schweizer M, Jesus B, Metzger E, Geslin E. Response of a kleptoplastidic foraminifer to heterotrophic starvation: photosynthesis and lipid droplet biogenesis. FEMS Microbiol Ecol. 2019;95:fiz046.

15. Grzymski J, Schofield OM, Falkowski PG, Bernhard JM. The function of plastids in the deep-sea benthic foraminifer, Nonionella stella. Limnol Oceanogr. 2002;47:1569-80.

16. Pillet $L$, de Vargas $C$, Pawlowski J. Molecular identification of sequestered diatom chloroplasts and kleptoplastidy in foraminifera. Protist. 2011;162:394-404.

17. Cesbron F, Geslin E, Le Kieffre C, Jauffrais T, Nardelli MP, Langlet D, et al. Sequestered chloroplasts in the benthic foraminifer Haynesina germanica: cellular organization, oxygen fluxes and potential ecological implications. J Foraminifer Res. 2017;47:268-78.

18. Jauffrais T, Jesus B, Metzger E, Mouget JL, Jorissen F, Geslin E. Effect of light on photosynthetic efficiency of sequestered chloroplasts in intertidal benthic foraminifera (Haynesina germanica and Ammonia tepida). Biogeosciences. 2016;13:2715-26.

19. Lopez E. Algal chloroplasts in the protoplasm of three species of benthic foraminifera: taxonomic affinity, viability and persistence. Mar Biol. 1979;53:201-11.

20. Clark KB, Jensen KR, Stirts HM. Survey for functional kleptoplasty among West Atlantic Ascoglossa (=Sacoglossa) (Mollusca: Opisthobranchia). Veliger. 1990;33:339-45.

21. Rumpho ME, Dastoor F, Manhart J, Lee J. The kleptoplast. In: Wise RR, Hoober JK, editors. The structure and function of plastids. 23. New York: Advances in Photosynthesis and Respiration; 2006. p. 451-73.

22. Jesus B, Ventura $P$, Calado $G$. Behaviour and a functional xanthophyll cycle enhance photo-regulation mechanisms in the solar-powered sea slug Elysia timida (Risso, 1818). J Exp Mar Biol Ecol. 2010;395:98-105.

23. Hansen PJ, Fenchel T. The bloom-forming ciliate Mesodinium rubrum harbours a single permanent endosymbiont. Mar Biol Res. 2006;2:169-77.

24. Hansen PJ, Ojamäe K, Berge T, Trampe EC, Nielsen LT, Lips I, et al. Photoregulation in a kleptochloroplastidic dinoflagellate Dinophysis acuta. Front Microbiol. 2016;7:1-11.

25. Decelle J, Colin S, Foster RA. Photosymbiosis in Marine Planktonic Protists. In: Ohtsuka S, Suzaki T, Horiguchi T, Suzuki N, Not F, editors. Marine Protists. Tokyo: Springer; 2015. p. 465-500.

26. Stoecker DK, Johnson MD, deVargas C, Not F. Acquired phototrophy in aquatic protists. Aquat Micro Ecol. 2009;57:279-310.

27. Rumpho ME, Summer EJ, Manhart JR. Solar-powered sea slugs. Mollusc/algal chloroplast symbiosis. Plant Physiol. 2000;123:29-38.

28. Park MG, Park JS, Kim M, Yih W. Plastids dynamics during survival of Dinophysis caudate without its ciliate prey. J Phycol. 2008:44:1154-63.

29. Alexander SP, Banner FT. The functional relationship between skeleton and cytoplasm in Haynesina germanica (Ehrenberg). J Foraminifer Res. 1984;14:159-70.

30. Bernhard JM, Alve E. Survival, ATP pool, and ultrastructural characterization of benthic foraminifera from Drammens fjord (Norway): Response to anoxia. Mar Micropaleontol. 1996;28:5-17.

31. Bernhard JM, Bowser SS. Benthic foraminifera of dysoxic sediments: chloroplast sequestration and functional morphology. Earth Sci Rev. 1999;46:149-65.

32. Bernhard JM, Buck KR, Farmer MA, Bowser SS. The Santa Barbara Basin is a symbiosis oasis. Nature. 2000;403:77-80.

33. Correia MJ, Lee JJ. Chloroplast retention by Elphidium excavatum (Terquem). Is it a selective process? Symbiosis. 2000;29:343-55.

34. Lee JJ, Lanners E, Ter Kuile B. The retention of chloroplasts by the foraminifera Elphidium crispum. Symbiosis. 1988;5:45-60.

35. Cedhagen T. Retention of chloroplasts and bathymetric distribution in the sublittoral foraminiferan Nonionellina labradorica. Ophelia. 1991;33:17-30.

36. Correia MJ, Lee JJ. Fine structure of the plastids retained by the foraminifer Elphidium excavatum (Terquem). Symbiosis. 2002;32:15-26. 
37. Correia MJ, Lee JJ. How long do the plastids retained by Elphidium excavatum (Terquem) last in their host? Symbiosis. 2002;32:27-37.

38. Goldstein ST, Bernhard JM, Richardson EA. Chloroplast sequestration in the foraminifer Haynesina germanica: application of high pressure freezing and freeze substitution. Microsc Microanal. 2004;10:1458-9.

39. Jauffrais $T$, LeKieffre $C$, Koho KA, Tsuchiya $M$, Schweizer $M$, Bernhard JM, et al. Ultrastructure and distribution of kleptoplasts in benthic foraminifera from shallow-water (photic) habitats. Mar Micropaleontol. 2018;138:46-62.

40. Tsuchiya M, Toyofuku T, Uematsu K, Brüchert V, Collen J, Yamamoto $H$, et al. Cytologic and genetic characteristics of endobiotic bacteria and kleptoplasts of Virgulinella fragilis (Foraminifera). J Euk Microbiol. 2015;62:454-69.

41. Tsuchiya M, Miyawaki S, Oguri K, Toyofuku T, Tame A, Uematsu K, et al. Acquisition, Maintenance, and Ecological Roles of Kleptoplasts in Planoglabratella opercularis (Foraminifera, Rhizaria). Front Mar Sci. 2020;7:585.

42. Jauffrais T, Jesus B, Méléder V, Geslin E. Functional xanthophyll cycle and pigment content of a kleptoplastic benthic foraminifer: Haynesina germanica. PLOS ONE. 2017;12:e0172678.

43. Austin HA, Austin WE, Paterson DM. Extracellular cracking and content removal of the benthic diatom Pleurosigma angulatum (Quekett) by the benthic foraminifera Haynesina germanica (Ehrenberg). Mar Micropaleontol. 2005; 57:68-73.

44. Green BJ, Li WY, Manhart JR, Fox TC, Summer EJ, Kennedy RA, et al. Mollusc-algal chloroplast endosymbiosis. Photosynthesis, thylakoid protein maintenance, and chloroplast gene expression continue for many months in the absence of the algal nucleus. Plant Physiol. 2000;124:331-42.

45. Nagai S, Nitshitani G, Tomaru Y, Sakiyama S, Kamiyama T. Predation by the toxic dinoflagellate Dinophysis fortii on the ciliate Myrionecta rubra and observation of sequestration of ciliate chloroplasts. J Phycol. 2008;44:909-22.

46. Shi LX, Theg SM. The chloroplast protein import system: From algae to trees. Biochim Biophys Acta. 2013;1833:314-31.

47. de Vries J, Habicht J, Woehle C, Huang C, Christa G, Waegele H, et al. Is ftsH the key to plastid longevity in sacoglossan slugs? Genome Biol Evol. 2013;5:2540-8.

48. Cruz S, Cartaxana P, Newcomer R, Dionísio G, Calado R, Serôdio J, et al. Photoprotection in sequestered plastids of sea slugs and respective algal sources. Sci Rep. 2015;5:1-8.

49. Cartaxana P, Morelli L, Jesus B, Calado G, Calado R, Cruz S. The photon menace: kleptoplast protection in the photosynthetic sea slug Elysia timida. J Exp Biol. 2019;222:jeb202580

50. Petrou K, Ralph P, Nielsen D. A novel mechanism for host-mediated photoprotection in endosymbiotic foraminifera. ISME J. 2017;11:453-62.

51. Darling KF, Schweizer M, Knudsen KL, Evans KM, Bird C, Roberts A, et al. The genetic diversity, phylogeography and morphology of Elphidiidae (Foraminifera) in the Northeast Atlantic. Mar Micropaleontol. 2016;129:1-23.

52. Kühl M, Polerecky L. Functional and structural imaging of aquatic phototrophic microbial communities and symbioses. Aquat Microb Ecol. 2008;53:99-118.

53. Rouse JW, Haas RH, Schell JA, Deering DW. Monitoring vegetation systems in the great plains with ERTS. Proc Third ERTS Symp. 1973;1:309-17.

54. Barillé $L$, Mouget JL, Méléder $V$, Rosa $P$, Jesus $B$. Spectral response of benthic diatoms with different sediment backgrounds. Remote Sens Environ. 2011;115:1034-42.

55. Kazemipour F, Launeau $P$, Méléder V. Microphytobenthos biomass mapping using the optical model of diatom biofilms: application to hyperspectral images of Bourgneuf Bay. Remote Sens Environ. 2012;127:1-13.

56. Meleder V, Barille L, Launeau P, Carrere V, Rince Y. Spectrometric constraint in analysis of benthic diatom biomass using monospecific cultures. Remote Sens Environ. 2003;88:386-400.

57. Serôdio J, Pereira S, Furtado J, Silva R, Coelho H, Calado R. In vivo quantification of kleptoplastic chlorophyll a content in the "solar-powered" sea slug Elysia viridis using optical methods: spectral reflectance analysis and PAM fluorometry. Photochem Photobiol Sci. 2010;9:68-77.

58. Jesus B, Mouget J-L, Perkins RG. Detection of diatom xanthophyll cycle using spectral reflectance. J Phycol. 2008:44:1349-59.

59. Jesus B, Rosa P, Mouget JL, Méléder V, Launeau P, Barillé L. Spectral-radiometric analysis of taxonomically mixed microphytobenthic biofilms. Remote Sens Environ. 2014;140:196-205.

60. Louchard EM, Reid RP, Stephens CF, Davis CO, Leathers RA, Downes TV, et al. Derivative analysis of absorption features in hyperspectral remote sensing data of carbonate sediments. Opt Express. 2002;10:1573-84.

61. Perkins RG, Williamson CJ, Brodie J, Barillé L, Launeau P, Lavaud J, et al. Microspatial variability in community structure and photophysiology of calcified macroalgal microbiomes revealed by coupling of hyperspectral and highresolution fluorescence imaging. Sci Rep. 2016;6:1-14.

62. Trampe E, Kolbowski J, Schreiber U, Kühl M. Rapid assessment of different oxygenic phototrophs and single-cell photosynthesis with multicolour variable chlorophyll fluorescence imaging. Mar Biol. 2011;158:1667-75.
63. Ralph PJ, Schreiber U, Gademann R, Kühl M, Larkum AWD. Coral photobiology studied with a new imaging pulse imaging pulse amplitude modulated fluorometer. J Phycol. 2005;41:335-42.

64. Platt T, Gallegos CL, Harrison WG. Photoinhibition of photosynthesis in natural assemblages of marine phytoplancton. J Mar Res. 1980;38:687-701.

65. Kühl M, Glud RN, Borum J, Roberts R, Rysgaard S. Photosynthetic performance of surface associated algae below sea ice as measured with a pulse amplitude modulated (PAM) fluorometer and $\mathrm{O} 2$ microsensors. Mar Ecol Progr Ser S. 2001;223:1-14.

66. Harrison WG, Platt T. Photosynthesis-irradiance relationships in polar and temperate phytoplankton populations. Polar Biol. 1986;5:153-64.

67. Elzhov TV, Mullen KM, Spiess A-N, Bolker B minpack.Im: $R$ Interface to the Levenberg-Marquardt Nonlinear Least-Squares Algorithm Found in MINPACK Plus Support for Bounds. 2016 R package version 1.2-1. https://CRAN.R-project. org/package $=$ minpack.Im.

68. LeKieffre C, Spangenberg JE, Mabilleau G, Escrig S, Meibom A, Geslin E. Surviving anoxia in marine sediments: the metabolic response of ubiquitous benthic foraminifera (Ammonia tepida). PLOS ONE. 2017;12:e0177604.

69. Bernhard JM. Distinguishing live from dead foraminifera: Methods review and proper applications. Micropaleontol. 2000;46:38-46.

70. Nomaki H, Bernhard JM, Ishida A, Tsuchiya M, Uematsu K, Tame A, et al. Intracellular isotope localization in Ammonia sp. (Foraminifera) of oxygen-depleted environments: results of nitrate and sulfate labeling experiments. Front Microbiol. 2016;7:1-12.

71. Eaton JW, Moss B. Estimation of numbers and pigment content in epipelic algal populations. Limnol Oceanogr. 1966;11:584-95.

72. Schneider CA, Rasband WS, Eliceiri K. NIH Image to ImageJ: 25 years of image analysis. Nat Meth. 2012;9:671-5.

73. $\mathrm{R}$ Core Team. R: A language and environment for statistical computing. $\mathrm{R}$ Foundation for Statistical Computing 2017, Vienna, Austria. URL https://www.Rproject.org/.

74. Schneider LK, Anestis K, Mansour J, Anschütz AA, Gypens N, Hansen PJ, et al. A dataset on trophic modes of aquatic protists. Biodivers Data J. 2020;8:e56648.

75. Banner FT, Culver SJ. Quaternary Haynesina n. gen. and paleogene Protelphidium Haynes; their morphology, affinities and distribution. J Foraminifer Res. 1978;8:177-207.

76. Hansen HJ, Lykke-Andersen AL. Wall structure and classification of fossil and recent elphidiid and nonionid Foraminifera. Foss Strat. 1976;10:1-37.

77. Hottinger L, Reiss Z, Langer M. Spiral canals of some Elphidiidae. Micropaleontol. 2001;47:5-34.

78. Lee J. On a piece of chalk - Update. J Euk Microbiol. 1993;40:395-410.

79. Passarelli C, Meziane T, Thiney N, Boeuf D, Jesus B, et al. Seasonal variations of the composition of microbial biofilms in sandy tidal flats: Focus of fatty acids, pigments and exopolymers. Estuar Coast Shelf Sci. 2015;153:29-37.

80. Jauffrais T, Drouet S, Turpin V, Méléder V, Jesus B, Cognie B, et al. Growth and biochemical composition of a microphytobenthic diatom (Entomoneis paludosa) exposed to shorebird (Calidris alpina) droppings. J Exp Mar Biol Ecol. 2015;469:83-92.

81. Jauffrais $T$, Jesus $B$, Méléder $V$, Turpin $V$, Russo ADAPG, Raimbault $P$, et al. Physiological and photophysiological responses of the benthic diatom Entomoneis paludosa (Bacillariophyceae) to dissolved inorganic and organic nitrogen in culture. Mar Biol. 2016:163:1-14.

82. Meleder V, Laviale M, Jesus B, Mouget JL, Lavaud J, Kazemipour F, et al. In vivo estimation of pigment composition and optical absorption cross-section by spectroradiometry in four aquatic photosynthetic micro-organisms. J Photochem Photobio B-Biol. 2013;129:115-24.

83. Knight R, Mantoura RFC. Chlorophyll and carotenoid pigments in foraminifera and their symbiotic algae: analysis by high performance liquid chromatography. Mar Ecol Prog Ser. 1985;23:241-9.

84. Ralph PJ, Gademann R. Rapid light curves: a powerful tool to assess photosynthetic activity. Aquat Bot. 2005;82:222-37.

85. Olaizola M, Yamamoto HY. Short term response of the diadinoxanthin cycle and fluorescence yield to high irradiance in Chaetoceros muelleri (Bacillariophyceae). J Phycol. 1994;30:606-12.

86. Lavaud J, Rousseau B, Etienne A-L. General features of photoprotection by energy dissipation in planktonic diatoms (Bacillariophyceae). J Phycol. 2004;40:130-7.

87. Ventura P, Calado G, Jesus B. Photosynthetic efficiency and kleptoplast pigment diversity in the sea slug Thuridilla hopei (Vérany, 1853). J Exp Mar Biol Ecol. 2013;441:105-9.

88. Martin R, Walther $\mathrm{P}$, Tomaschko $\mathrm{KH}$. Variable retention of kleptoplast membranes in cells of sacoglossan sea slugs: plastids with extended, shortened and nonretained durations. Zoomorphology. 2015;134:523-9.

89. Bird C, Schweizer M, Roberts A, Austin WEN, Knudsen KL, Evans KM, et al. The genetic diversity, morphology, biogeography, and taxonomic designations of Ammonia (Foraminifera) in the Northeast Atlantic. Mar Micropaleontol. 2020;155:101726 


\section{ACKNOWLEDGEMENTS}

The authors thank Romain Mallet for his help at the Imaging core facility (SCIAM) of the University of Angers (MEB images) and Sofie Jakobsen for her technical assistance during work in Denmark. TJ was funded by the "FRESCO" project, a project supported by the Region Pays de Loire and the University of Angers. CL was funded by the Swiss National Science Foundation (grant no. 200021_149333). The work was further supported by the French national programme CNRS EC2CO-LEFE project "ForChlo", a French-Danish research collaboration grant of the Institut Français du Danemark (BJ, MK), a grant from the Independent Research Fund Denmark | Technical and Production Sciences (MK; DFF-8022-00301B), an infrastructure grant from the Carlsberg Foundation (MK) and the BIO-Tide project, funded through the 2015-2016 BiodivERsA COFUND call for research proposals, with the national funders BelSPO, FWO, ANR and SNSF. The electron microscopy platform of the University of Lausanne is thanked for access to the equipment and technical assistance.

\section{AUTHOR CONTRIBUTIONS}

Conceptualisation: BJ, TJ. Methodology: BJ, TJ, ET, JG, MK, EG. Investigation: BJ, TJ, ET, $\mathrm{CL}$. Writing-original draft: $\mathrm{BJ}, \mathrm{TJ}, \mathrm{CL}$, MK. Writing-review \& editing: $\mathrm{BJ}, \mathrm{TJ}, \mathrm{JG}, \mathrm{CL}$, AM, MK, EG. Funding acquisition: BJ, MK, AM, EG.

\section{COMPETING INTERESTS}

The authors declare no competing interests.

\section{ADDITIONAL INFORMATION}

Supplementary information The online version contains supplementary material available at https://doi.org/10.1038/s41396-021-01128-0.

Correspondence and requests for materials should be addressed to Bruno Jesus.

Reprints and permission information is available at http://www.nature.com/ reprints

Publisher's note Springer Nature remains neutral with regard to jurisdictional claims in published maps and institutional affiliations.

Attribution 4.0 International License, which permits use, sharing, adaptation, distribution and reproduction in any medium or format, as long as you give appropriate credit to the original author(s) and the source, provide a link to the Creative Commons license, and indicate if changes were made. The images or other third party material in this article are included in the article's Creative Commons license, unless indicated otherwise in a credit line to the material. If material is not included in the article's Creative Commons license and your intended use is not permitted by statutory regulation or exceeds the permitted use, you will need to obtain permission directly from the copyright holder. To view a copy of this license, visit http://creativecommons.org/licenses/by/4.0/.

(c) The Author(s) 2021 